\title{
The Relationship between non-Performing Loans and Selected EU Members Banks Profitabilities
}

\author{
Huseyin Cetin
}

\begin{abstract}
Between the time period of 2005-2015, it has been found that non-performing loans and return on assets is negatively correlated for many EU members banks. Panel data OLS regression analysis was applied. Between the time period of 2005-2015, it has been found that non-performing loans had significant negative impact on return on asset ratios for $10 \mathrm{EU}$ members banks panel data. Bayesian impulse response analysis was applied to panel data of 10 countries. According to analysis, between 2005-2015, one standard deviation positive shock of non-performing loans diminished return on asset ratios. It can be indicated that Bayesian impulse response analysis has similar result with Panel OLS regression. The research results support bad management hypothesis. In addition, Johansen Fisher Panel Cointegration test was used and it has been found that there is long term relationship between some EU members banks NPL and ROA.
\end{abstract}

Index Terms-EU members banks, NPL, panel data, ROA.

\section{INTRODUCTION}

According to [1], non-performing loans are thought as component of probability. According to[1],via problematic debts; high amount of non-performing loans negatively influence banks net profits.

According to [2], weakness in the financial system has strong correlation with NPL. There is important correlation between the rise of NPL and banking crises.

Ref. [3] indicated that the augmentation in NPLs can be used to show the onset of a banking crisis, while [4] adviced the use of NPLs to observe the weakness of the financial system.

Banks uses statistical techniques to minimize NPL ratios which diminishes profitability of banks. Banks have extra costs when NPL ratios increase. In other words, loan loss provision will increase.

Risk always exists in banking system. Customer who can regularly pay off the debt may not be able to pay off the debt if default occurs in economy. Default can occur any time in any economy.

Since EU countries are connected with each other, even one crisis in small economies in EU can depreciate the value of Euro against other currencies and that circumstance also influences big economies in EU countries. Although interest rates are low in EU countries, customers may not be able to pay off the debts.

The main objective of that research is to find the

Manuscript received June 25, 2018; revised March 1, 2019.

Huseyin Cetin is with the Bursa Technical University, Bursa, Turkey (e-mail: huseyin.cetin@btu.edu.tr). relationship between EU members banks NPL ratios and ROA which is one of the profitability ratio of the banks.

\section{LITERATURE REVIEW}

Ref. [5] used Generalized Method of Moments methodology and found that NPL had a statistically important adverse influence on 34 Vietnamese commercial banks profitabilities between 2005 and 2015 .

Ref. [6] found that NPL ratio had negative relationship with banks technical efficiency for Korean commercial banks between 1995-2005.

For the period of 1993-1996, [7] found that there was a negative relationship between NPLs ratio and Japanese commercial banks' performance.

Ref. [8] researched about the components of Turkish banks lending behaviour, found an important relationship between Turkish banks NPLs and lending behaviour for state owned banks and confirming the negative influence on NPLs on the augmentation of total loans.

Ref. [9] researched about the relationship between NPL and bank efficiency in Malaysia and Singapore and unearthed that a high amount of NPL diminished banks cost efficiency. That circumstance adversely influences profitability.

Contrary with other research findings, from the period of 2005 and 2009, [10] researched about the relationship between commercial banks profitability and credit risk in Ghana unearthed that credit risk has a slight influence on banks' profits.

Ref. [11] found that non-performing loans had a significant negative influence on EU member banks profitability for the period between 2003-2011.

By using fixed effects and dynamic-GMM methodology, between the period of 1984-2013, [12] found that greater capitalization, liquidity risks, poor credit quality, high cost inefficiency and banking industry size significantly augmented NPLs, while high bank profitability diminishes NPLs for all commercial banks and savings institutions across 50 US States and the District of Columbia.

By using 16 commercial banks panel data in Tanzania [13] unearthed that non-performing loans had negative relationship with commercial bank profitability between the period of 2007-2015.

\section{THEORETICAL FRAMEWORK}

Information Asymmetry Theory and Bad Management Hypothesis was used by [13] in their research paper.

Information Asymmetry Theory indicates that 
asymmetric information exists when one party in a transactional relationship have more information about the transaction than the other party. In the financial decision space, asymmetric information literature analyzes the influence of decisions based on the difference in the information available to both parties [14].

Lenders offering credit facilities to borrowers face uncertainty of loan repayment, Lenders can not analyze the characteristics and behaviours of the borrower, and for that reason, it is difficult to evaluate the borrower [15].

Bad Management Hypothesis: Due to the adverse selection, bank management tends to give more resources for managing and analyzing bad loans, that leads to augment the operating expenses over the increase in interest income, leads to higher cost to-income ratio [16].

\section{Methodology}

In that research, 19 EU countries banks NPL and ROA data were collected. Since remaining EU countries data were not complete, those countries were not included in correlation analysis. According to Table I, following results were found for the period between 2005-2015. 10 countries were found to have at least medium level of correlation. Thus those 10 countries were evaluated in panel regression analysis.

According to Hausman test result (Table II), fixed effect test will be used for $10 \mathrm{EU}$ members banks.

$\left(Y=\beta \dot{X}_{i t}+\alpha_{i}+u_{i t}\right)$ model will be used for fixed effect. $Y$ corresponds to dependent variable which is ROA. $X_{i t}$ is a vector of regressors which is used to explain the dependent variable. $\alpha_{\mathrm{i}}$ is unknown intercept and $u_{i t}$ is error term.

According to Panel OLS (Fixed effect) model (Table III), NPL ratio has significant adverse impact on 10 EU countries banks ROA ratios panel data. NPL and Z score can explain the changes of 10 EU countries banks' ROA ratios panel data by $\% 52$ percent.

According to Table IV, there is cross section dependence for panel data residuals. In panel data, countries are influenced by each other. Cross-section dependence is important prerequisite for panel data analysis. EU countries are interconnected with each other. Therefore, there can be cross sectional dependence between EU countries banks. In addition, since small sample size is used results are still valid.

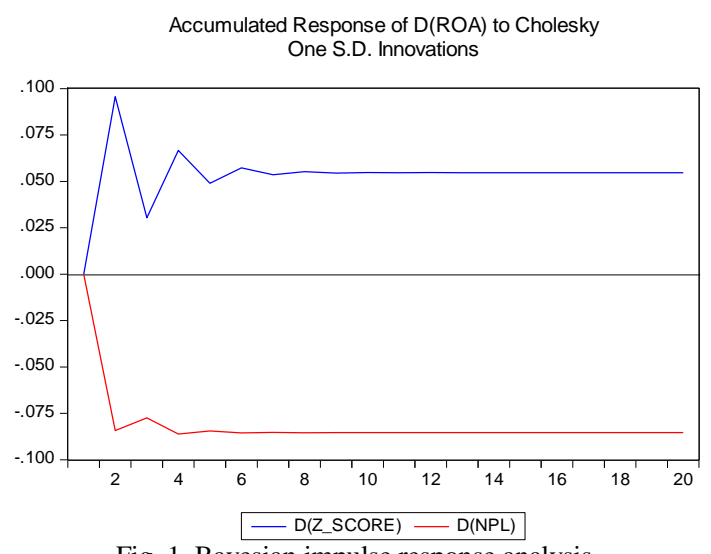

Fig. 1. Bayesian impulse response analysis.

Moreover, Bayesian impulse response analysis was implemented for panel data. Schwarz Information Criteria was used. Optimal lag number was taken as 1. Data were first differenced and there was no stationary problem. According to Fig. 1, when one standard deviation positive shock of NPL is given to 10 EU countries banks, ROA ratio diminishes and back to equilibrium after 4 years. It can be indicated that Bayesian impulse response analysis corresponds with Panel Data OLS with fixed effect.

TABLE I: CORRELATION ANALYSIS OF 19 EU COUNTRIES

\begin{tabular}{|l|l|}
\hline Correlation: NPL-ROA $(2005-2015)$ & Correlation Degree \\
\hline Austria & -0.28 \\
\hline Belgium & 0.36 \\
\hline Bulgaria & $\mathbf{- 0 . 5 6}$ \\
\hline Croatia & $\mathbf{- 0 . 8 2}$ \\
\hline Czech Rep. & -0.19 \\
\hline France & 0.15 \\
\hline Greece & -0.21 \\
\hline Hungary & $\mathbf{- 0 . 9 1}$ \\
\hline Ireland & -0.35 \\
\hline Italy & $\mathbf{- 0 . 6 5}$ \\
\hline Lithuania & $\mathbf{- 0 . 6 3}$ \\
\hline Malta & 0.16 \\
\hline Romania & $\mathbf{- 0 . 7 7}$ \\
\hline Slovak Rep. & $\mathbf{- 0 . 5 2}$ \\
\hline Spain & $\mathbf{- 0 . 5 9}$ \\
\hline Estonia & $\mathbf{- 0 . 4 8}$ \\
\hline Latvia & $\mathbf{- 0 . 8 4}$ \\
\hline Poland & 0.50 \\
\hline Sweden & -0.19 \\
\hline
\end{tabular}

TABLE II: HAUSMAN TEST

\begin{tabular}{|l|l|l|l|}
$\begin{array}{l}\text { Correlated Random Effects- } \\
\text { Hausman Test }\end{array}$ & $\begin{array}{l}\text { Chi-Sg } \\
\text { Statistic }\end{array}$ & $\begin{array}{l}\text { Chi- } \\
\text { Sg.df. }\end{array}$ & Prob. \\
\hline Cross section random & 37.09 & 2 & 0.00 \\
\hline
\end{tabular}

TABLE III: PANEL OLS RESULT

\begin{tabular}{|l|l|l|}
\hline Dependent Variable: ROA & Coefficient & Prob. \\
\hline C & -1.59 & 0.02 \\
\hline NPL & -0.14 & 0.00 \\
\hline Z_SCORE & 0.39 & 0.00 \\
\hline R Square $=0.52$ & No Time Fixed Effect & $\begin{array}{l}\text { Durbin } \\
\text { Watson }=1.89\end{array}$ \\
\hline
\end{tabular}

TABLE IV: CROSS SECTION DEPENDENCE TESTS

\begin{tabular}{|l|l|}
\hline Residual Cross Section Dependence Test & Prob. \\
\hline Breusch-Pagan LM & 0.000 \\
\hline Pesaran scaled LM & 0.001 \\
\hline Bias-corrected scaled LM & 0.007 \\
\hline Pesaran CD & 0.038 \\
\hline
\end{tabular}

TABLE V: GRANGER CAUSALITY TEST

\begin{tabular}{|l|l|l|}
\hline Lag Number: 1 & Observation & Probability \\
\hline NPL does not Granger Cause ROA & 100 & 0.03 \\
\hline ROA does not Granger Cause NPL & 100 & 0.14 \\
\hline
\end{tabular}

Moreover, Granger causality test(Table V) was conducted between NPL and ROA. It has been found that there is unidirectional relationship between NPL and ROA of the 10 EU countries banks. After implementing Granger causality analysis, Johansen Fisher Panel Cointegration test will be used.

According to Table VI, null hypothesis of no- 
cointegration is rejected and at most 1 cointegrating relationship was accepted. Since fixed effects is used, individual intercept assumption was used. In addition, it was assumed that there is no deterministic trend in data.

TABLE VI: JoHANSEN Fisher PANEL COINTEGRATION TEST

\begin{tabular}{|l|l|}
\hline Johansen Fisher Panel Cointegration Test Result & Probability \\
\hline None & 0.00 \\
\hline At Most 1 & 0.09 \\
\hline
\end{tabular}

TABLE VII: COINTEGRATING RELATIONSHIPS

\begin{tabular}{|ccccc|}
\hline Cross Section & Statistics & Prob. ${ }^{* *}$ & Statistics & Prob. $^{* *}$ \\
\hline Hypothesis of no cointegration & & & \\
\hline Bulgaria & $\mathbf{3 6 . 7 9 7 4}$ & $\mathbf{0 . 0 0 0 1}$ & $\mathbf{3 0 . 8 0 4 2}$ & $\mathbf{0 . 0 0 0 1}$ \\
\hline Croatia & 15.9467 & 0.1769 & 11.4560 & 0.2198 \\
\hline Hungary & $\mathbf{2 3 . 7 1 8 4}$ & $\mathbf{0 . 0 1 6 1}$ & $\mathbf{2 0 . 0 0 3 2}$ & $\mathbf{0 . 0 1 0 6}$ \\
\hline Italy & $\mathbf{2 2 . 6 9 0 6}$ & $\mathbf{0 . 0 2 2 7}$ & $\mathbf{1 5 . 9 4 6 9}$ & $\mathbf{0 . 0 4 9 0}$ \\
\hline & & & & \\
Lithuania & 20.2123 & 0.0508 & 14.3664 & 0.0855 \\
\hline Romania & $\mathbf{2 7 . 8 3 3 7}$ & $\mathbf{0 . 0 0 3 7}$ & $\mathbf{2 0 . 1 6 5 3}$ & $\mathbf{0 . 0 1 0 0}$ \\
\hline Slovak & 10.2670 & 0.6136 & 6.2401 & 0.7606 \\
\hline Spain & 17.1924 & 0.1255 & 11.1031 & 0.2443 \\
\hline Estonia & $\mathbf{2 8 . 7 3 5 7}$ & $\mathbf{0 . 0 0 2 7}$ & $\mathbf{2 2 . 8 8 0 0}$ & $\mathbf{0 . 0 0 3 4}$ \\
\hline Latvia & $\mathbf{2 3 . 1 5 4 1}$ & $\mathbf{0 . 0 1 9 4}$ & $\mathbf{1 9 . 3 5 8 3}$ & $\mathbf{0 . 0 1 3 7}$ \\
\hline Hypothesis of at & & & \\
\hline Bulgaria & 5.9933 & 0.1912 & 5.9933 & 0.1912 \\
\hline cointegration relationship & & \\
\hline Croatia & 4.4907 & 0.3439 & 4.4907 & 0.3439 \\
\hline Hungary & 3.7152 & 0.4562 & 3.7152 & 0.4562 \\
\hline Italy & 6.7437 & 0.1406 & 6.7437 & 0.1406 \\
\hline Lithuania & 5.8459 & 0.2030 & 5.8459 & 0.2030 \\
\hline Romania & 7.6684 & 0.0954 & 7.6684 & 0.0954 \\
\hline Slovak & 4.0269 & 0.4081 & 4.0269 & 0.4081 \\
\hline Spain & 6.0892 & 0.1839 & 6.0892 & 0.1839 \\
\hline Estonia & 5.8557 & 0.2022 & 5.8557 & 0.2022 \\
\hline Latvia & 3.7958 & 0.4434 & 3.7958 & 0.4434 \\
\hline & & & & \\
\hline
\end{tabular}

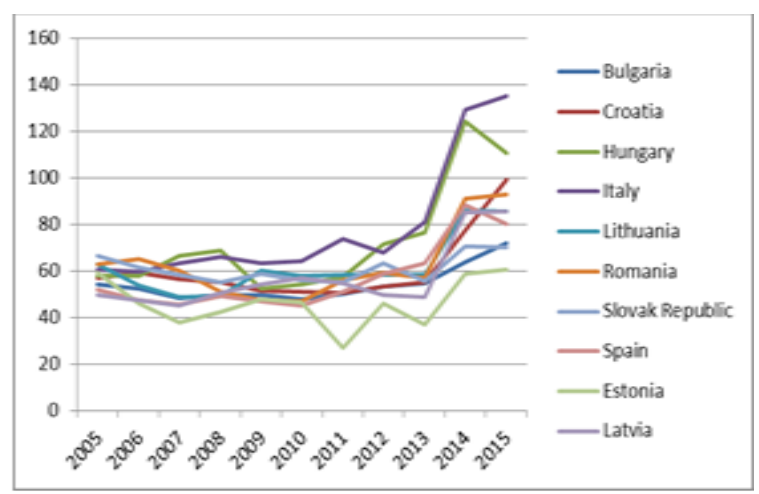

Fig. 2. Cost/Income trend.

In Table VII, cointegrating relationships between NPL and ROA were found. When hypothesis of cointegration was analyzed, it can be seen that Bulgaria, Hungary, Italy, Romania, Estonia, Latvia NPL and ROA ratios are cointegrated. In addition, Croatia, Lithuania, Slovak Republic, Spain NPL and ROA ratios are not cointegrated. When hypothesis of at most 1 cointegration relationship is analyzed, each country has at most 1 cointegrated relationship between NPL and ROA. Moreover, no cointegrating relationship was found for Croatia, Lithuania, Slovakia and Spain.

Moreover, Fig. 2 indicates the Cost/Income trend of 10 EU members banks. Data were retrieved from Global Financial Development database. According to Fig. 2, from 2005, Cost/Income ratio increased fast for many countries. That increases confirms bad management hypothesis. It can be indicated that due to adverse selection and NPL, those countries banks operating expenses have increased fast.

\section{CONCLUSION}

In that research, relationship between NPL and ROA of selected EU member countries is mainly negative for the period between 2005-2015. Panel OLS regression analysis was also conducted for the period between 2005-2015. It has been found that NPL had significant negative influence on selected EU members banks profitability. That research result has similarity with [11]'s research. It can be indicated that many European banks customers have difficulty when they pay back their debts. That circumstance adversely influenced many European banks profitability. Moreover, that situation mainly derives from 2008 global financial crisis. Before global financial crisis, interest rates in European banking system was not very low. After the global financial crisis, interest rates were under the \%0. That means when customers deposited money in the bank, they got negative return. Many customers may not be able to deposit their money due to the bad economic conditions. In addition, portfolio management system was not have sustainable returns for customers to pay back their debts. When economic conditions worsened, customers purchasing powers declined and lay off rates increased. Moreover, not only customers in EU have problems to pay off their debt, but also USA customers and developing nations customers have difficulty for paying off their debts. USA and EU members diminishes interest rates to stimulate their economies.

On the other hand, developing nations interest rates increased to attract more portfolio investments from overseas. Rising interest rates in developing nations temporarily overvalued the currencies of some developing nations but many developing countries currencies value diminished again and interest rates again increased sharply. That circumstance led non-performing loans to increase in developing nations as well.

Moreover, Bayesian impulse response analysis was implemented in that research. It was found that one standard deviation of positive shock of NPL diminishes selected EU members banks profitability. In addition, profitability in EU banking system was in equilibrium within 4 years. In addition to that, impulse response analysis corresponds with Panel OLS regression. It has been found that many EU member countries are sensitive to NPL. European banking system should be more strict to overcome the problem of NPL that plummetes EU member banks profitability. In addition to that, Granger causality analysis was applied for NPL-ROA relationship. It has been found that NPL can forecast ROA of $10 \mathrm{EU}$ members banks return on asset ratios panel data. There is one way relationship between ROA and NPL. Moreover, Johansen Fisher Panel Cointegration test was applied to analyze the long term relationship between NPL and ROA of 10 EU members banks. For panel data set, there is long term relationship between NPL and ROA. When panel data is cross sectionally analyzed, it can be indicated that there is long term relationship between NPL and ROA for 6 EU members banks. In addition, it has been found that there is at most 1 
cointegrating relationship for panel data set.

In addition, Cost/Income ratio increased fast for many European countries. It can be indicated that many EU members countries banks did not manage their cost efficiently. When costs increase, banks should also increase revenues to offset the cost increase impact.

In order to protect from the systematic risks shocks, banks in EU can roll out new risk management systems to decrease non-performing loans. More sophisticated statistical techniques can be used for prediction of probable non-performing loans. Moreover, artificial intelligence techniques can also be used for non-performing loans. Banks can use machine learning techniques to have more better information about customers. By using machine learning techniques, banks can analyze customers behaviours. With that technique, banks in EU can offer specific credit product to customers. With machine learning techniques, crisis scenarios can also be constructed. Past data can be analysed and customer behaviours can be measured and new products can be rolled out in crisis scenarios. Not only banks should analyze just for crisis scenario and they also have to use machine learning for different scenarios. That scenarios can be pre-crisis regime, crisis regime, after crisis regime and normal economic condition regime and good economic condition regime. Between those regimes, it is highly probable that customer behaviours are different. With different regimes, different credit products can be rolled out to diminish the nonperforming loans. Moreover, customer segmentation is also important. During statistical analysis for loan evaluation, different income groups and different occupations have different results. Logistic regression analysis can also be conducted to analyze output for different income groups and different occupations. Each year, results should be analysed and horizontal analysis can be applied for yearly changes. In each year, different income groups and different occupations groups credit payment scenario can be analysed and observations can be done with different clusters. For example, if banks diagnose problem with particular job and income group they can take precaution before giving loans. In some occupations, customer can lose their jobs and that people may not be able to pay their debt. That risky job groups should also be determined before giving loans. With that analyses, rising non-performing loans can decline. In addition to that, each EU member countries banks can extend those analyses to different cities. In each city, results can be different. They can diagnose non-performing loans problems for each city. For each cities, banks can develop new strategies before offering credit products. In addition to that, crisis loan system can also be implemented. New crisis loans can also be developed by marketing departments of banks. If sharp crisis occur in economy, many different income groups and many occupations groups may have difficulty to pay off their debt. They may use crisis loan temporarily and after economy is in good condition, customers may pay off their debt back. With that strategy, non-performing loans may also diminish. In addition, banks in EU can developed new deposit products for customers to effectively manage their money. With sustainable management of money, customers may be able to pay off their debt back during crisis periods. Morever, new insurance products for crisis can be developed. If customers are in default situation, that crisis insurance can pay off the debt of the customer. Banks can also develop new credit cards for crisis condition and they may diminish cash advance rates for customers to pay off their debts regularly. Lastly, banks in EU can increase non-interest income to offset the cost of non-performing loans.

\section{REFERENCES}

[1] M. K. Ombaba, "Assesing the factors contributing to nonperformance loans in Kenyan Banks," European Journal of Business and Management, pp. 155-162, 2013.

[2] V. Us, "Dynamics of non-performing loans in Turkish banking sector by an ownership breakdown: The impact of global financial crisis," Finance Research Letters, vol. 20, pp. 109-117, February 2017.

[3] C.M. Reinhart and K. S. Rogoff, "From financial crash to debt crisis," American Economic Review, pp. 1676-1706, August 2011.

[4] M. Sorge, "Stress-testing financial systems: An overview of current methodologies," BIS Working Paper No. 165, 2004.

[5] N. Vinh, "The impact of non-performing loans on bank profitability and lending behavior," Journal of Economic Development, pp. 27-44, 2016.

[6] R. Banker, H. Chang, and S. Lee, "Differential impact of Korean Banking system reforms on bank productivity," Journal of Banking \& Finance, pp. 1450-1460, 2010.

[7] Y. Altunbas, H. Liu, P. Molyneux, and R. Seth, "Efficiency and risk in Japanese Banking," Journal of Banking \& Finance, pp. 1605-1628, 2000.

[8] S. Tomak, "Determinants of commercial bank' lending behaviour: Evidence from Turkey," Asian Journal of Empirical Research, pp. 933-943, 2013.

[9] M. Z. A Karim, "Bank efficiency and non-performing loans: Evidence from Malaysia and Singapore," Prague Economic Papers, pp. 118-132, 2010.

[10] H. Samuel, D. Julius, and K. Samuel, "Credit risk and profitability of selected Banks in Ghana," Research Journal of Finance and Accounting, 2012.

[11] A. Roman and I. I. Tomulease, "Empirical evidence of commercial Banks in the new EU member States," in Proc. $14^{\text {th }}$ International Conference on Finance and Banking, Karvina, October 2013.

[12] A. Ghosh, "Banking industry specific and regional economic determinants of non-performing loans: Evidence from US States," Journal of Financial Stability, vol. 20, pp. 93-104, October 2015.

[13] P. S. Kingu, S. Macha, and R. Gwahula, "Impact of non-performing loans on bank's profitability: Empirical evidence from commercial banks in Tanzania," International Journal of Scientific Research and Management(IJSRM), vol. 6, pp. 71-79, January 2018.

[14] F. S. Mishkin, "Anatomy of financial crisis," Journal of Evolutionary Economics, vol. 2, pp. 115-130, June 1992.

[15] G. D. Ariccia, "Asymmetric information and the market structure of banking industry," IMF Working Papers WP/98/92, 1998.

[16] N. A. Berger and R. D. Young, "Problem loans and cost efficiency in commercial banks," Journal of Banking and Finance, vol. 21, 1997.

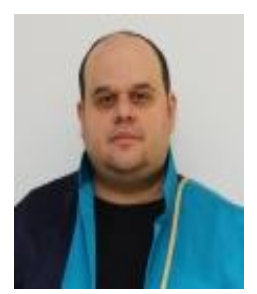

Hüseyin Çetin was born in April 12, 1986. He received his bachelor of management degree at Sabanc1 University, Turkey in January 2010, and his master of international business degree at Griffith University, Australia, in December 2010. He completed PhD programme at Okan University Social Science Institute, Istanbul, Turkey in December 2015. During the period of November 2014 to June 2015, Hüseyin Çetin was a research assistant at Okan University for entrepreneurship course. Hüseyin Çetin's research interest is finance, banking and international economics. He has published articles about banking and international finance. In addition, he attended to finance and mathematics conferences. He is an assistant professor at Bursa Technical University. He is one of the founders of International Trade and Logistics programme at Bursa Technical University. From 2016 to 2018, he was the head of Banking and Finance programme at Bursa Technical University as well. He gave lectures about business finance, investment and project appraisal, logistics cost analysis and fundamentals of international trade. 